The International Journal of Engineering and Science (IJES)

|| Volume || 6 || Issue || 7 || Pages || PP 41-47 || 2017 ||

ISSN (e): 2319 - 1813 ISSN (p): $2319-1805$

\title{
Development of Kampung Improvement Program in Surabaya, Indonesia
}

\author{
Anita Dianingrum ${ }^{1}$, Muhammad Faqih ${ }^{2}$, Dewi Septanti ${ }^{3}$ \\ ${ }^{I}$ Magister Student of Architecture Department, Institut Teknologi Sepuluh Nopember (ITS), Surabaya, \\ Indonesia \\ ${ }^{2}$ Lecturer of Architecture Department, Institut Teknologi Sepuluh Nopember (ITS), Surabaya, Indonesia \\ ${ }^{3}$ Lecturer of Architecture Department, Institut Teknologi Sepuluh Nopember (ITS), Surabaya, Indonesia \\ Corresponding author: Anita Dianingrum
}

\begin{abstract}
Kampung Improvement Program is still a priority because the majority of big cities in Indonesia are still dominated by informal settlements (kampung). Surabaya as the object of this research is one of the big cities that have a long history in the implementation of Kampung Improvement Program. However, there is no study that describes the periodization of Kampung Improvement Program development comprehensively. Therefore, this study aims to record the experience of Kampung Improvement Program in Surabaya comprehensively. This research used post-positivism paradigm with historical research strategy. Data collection was done by literature review and in-depth interview using qualitative descriptive analysis technique and triangulation. The result of this study is the period of Kampung Improvement Program development in Surabaya.
\end{abstract}

Keywords: Kampung Improvement Program, Surabaya City, periodization of development

Date of Submission: 10-06-2017

Date of Publication: 21-07-2017

\section{INTRODUCTION}

Cities in Indonesia are still dominated by informal settlements, where kampung is a word that can represent informal settlements in Indonesia (Budiarto (2003) in [1]). Kampung was the result of the transformation of the small village that had unique quality [2] and it built through a traditional and informal process by the inhabitants (Silas (1992) in [1]). However, kampung have low occupancy qualities as they are mostly inhabited by lowincome communities with minimal facilities and urban services (Silas (1992) \& Ford, L.R (1993) in [1]). On the other hand kampung is a good alternative to the sustainability of life in the city [3] and also still survives as the important development element of the city [2].

Therefore, the Kampung Improvement Program in Indonesia remains one of the most important priorities to improve environment quality and to support the Long-Term Development Plan (RPJP) 2005-2025, where one of the national development targets for 2025 is the city without settlement Slum (Cities Without Slums) [4]. The target of the RPJP is also intended to support one of the achievement targets of Sustainable Development Goals (SDGs).

The Kampung Improvement Program has been started since the Dutch government (1920s) known as Kampoeng Verbetering [3] where it was done in order to improve public health, because poor health of some people will affect to the other part [5]. The Kampung Improvement Program (KIP) began to be implemented in Jakarta and Surabaya in 1968 [6]. KIP is the first successful program to be recognized globally [7] and arguably the largest state-led program in some countries for more than three decades (Steinberg (1992) \& Silas (1992) in [8]). The activities undertaken are to integrate the role of government and society in improving the environment [9]. This program is considered to be very successful in solving environmental quality problems in an integrated manner [10] and also significantly reducing urban poverty (Steinberg (1992) \& Silas (1992) in [8]). The main objective of Kampung Improvement Program is community economic development and empowerment (Swanendri (2002) in [8]).

Surabaya is one of the cities that has long experience and has succeeded in implementing Kampung Improvement Program. This is evidenced by the many awards that have been achieved such as The Aga Khan Award for Architecture, 1986; UNEP Award, 1990; And The Habitat Award, 1991 [9].

There have been several studies that discussed the Kampung Improvement Program in Surabaya. But not many have recorded the experience of the Kampung Improvement Program comprehensively to be used as a lesson 
learned for Kampung Improvement Program in other cities. Therefore, this research is very important to record and describe the development of Kampung Improvement Program in Surabaya comprehensively.

\section{LITERATURE REVIEW}

According to [11], there are two housing provision systems that have been widely applied to development policies. The first housing provision system is a heteronomy / top-down. Where in this system, the most dominant role of government, so that this system only focus on physical approach. In the development of housing heteronomy system was considered not able to answer the housing problem. So the emergence of new housing provision system that is autonomy / bottom-up. This system based on local self-regulation, where the community has the greatest role. Because this system not only views the home as a once-physical result, it is a process associated with the socio-economic mobilization of the inhabitants. So this system not only focus on the physical approach, but already consider the social and economic dimensions approach.

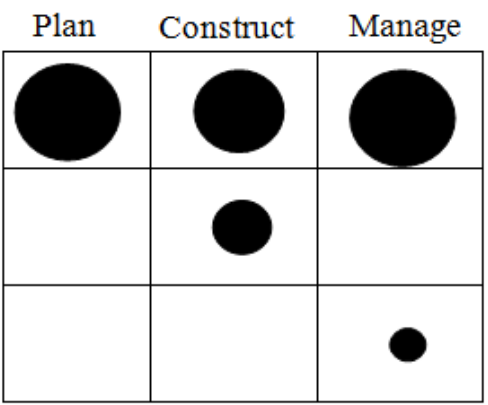

Centrally administrated or heteronomy housing system
Regulation or public sector

Suppliers or private sector

User or popular sector

Figure 1. Housing Provision System

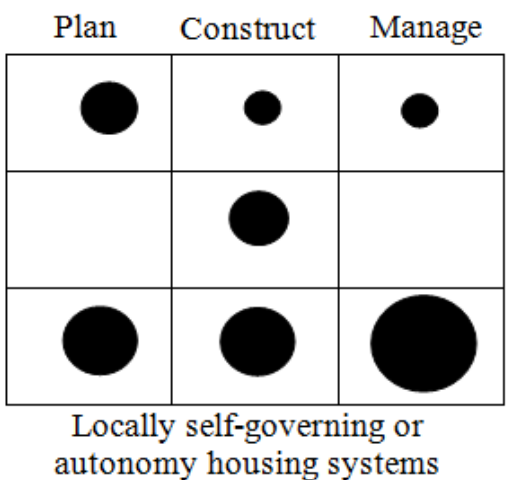

(Source : Turner,1976)

Turner (1976) also asserted that the community should more manage the provision process of hosing, so as to produce a better environment in the broad sense. There are three basic theories Turner (1976) associated with it are :

- When dwellers control the major decision and are free to make their own contribution to the design, construction and management, both the process and the resulting environment will improve the welfare of individuals or other communities. On the contrary, when people have no control and responsibility for important decisions and housing processes, dwelling environment may instead become a barrier to personal fulfillment and a burden to the family economy.

- The important thing about housing is not what it is, but what it does in people's live. In other words, the satisfaction of the occupants is not always parallel to the standard usage.

- Disadvantages and imperfections in housing are infinitely more tolerable if they are personal responsibility than if they are somebody else's.

The development of housing provision system can also be seen from the development of Kampung Improvement Program in Indonesia. Where the new view of the housing provision system is increasingly supported widely and openly. One of them is through Kampung Improvement Program (KIP), which is a government program to support community efforts in providing housing independently. But in reality, there are still many programs that are implemented just as part of the public works and physical development of the city with the application of heteronomy / top-down system. Because in the beginning the change in the concept of housing provision is mostly seen as a social service business, especially for low-income people. So much of the repair results quickly broken and opened up opportunities for graded and need to be rejuvenated [6]. From these conditions the government realizes that physical improvement is not sufficient. So that aspects of the improvements that are handled begin to increase. Where expected with the improvements of the physical environment can be achieved also improvements in terms of social and economic communities (there are multiplayer effect) [5], [12]. Over time, the Kampung Improvement Program continues to improve. Developed a new approach to the concept of Kampoung Improvement Program known as "kampong development with an integrated approach", where kampung development is seen as an interrelated process between the social, economic and physical environment, and should also be based on the participation of the kampung communities in the process [5], [13].

Based on several studies that have been conducted in relation to Kampung Improvement Programs such as research [5], [13], [14], [6], [15] and [12]. Physical improvements that have been handled in the development of 
Kampung Improvement Programs include infrastructure improvements, improvements in public facilities and physical improvement of the dwellings. As for improving the quality of life of the community that is realized by adding understanding and awareness of the community through counseling about the need and benefits of improved quality of life, followed by providing knowledge and skills to improve and maintain the quality of life. As for the improvement of the economic or business level of the community through the creation of new employment opportunities and enterprises, increased productivity and incomes of the villagers are realized by providing various facilities and assistance such as the provision of small credit with low interest and helping the marketing of their business results through cooperative efforts.

The aspects of improvement that have been addressed or resolved in the implementation of the improvement program are indirectly related to what has been given by the government to increase the potential or capacity of the community. Because according to [16] and [17], empowerment is a process to increase the capacity of individuals or groups to make choices and turn it into a desired action and outcome. In this aspect of empowerment, it can be seen what kind of empowerment or what government has given to community. It can also be seen at the stage where the position of empowerment is located. According to [18], there are four ways to apply empowerment, among others (1) empowerment through knowledge, (2) empowerment through statue, (3) empowerment through resourcing and (4) empowerment through agreement and power transfer either through grouping, participation, contribution, coordination or interaction [19], [20]. Meanwhile, according to Arai (1997) [21] there are four stages in the process of empowerment, among others are (1) awareness, (2) interaction and learning, (3) mobilization or action and (4) contribution.

In the opinion of [21] and [18], the approach in the empowerment process consists of a conventional / top-down approach and a community-based / bottom-up approach. A top-down approach can lead to an attachment because it is understood as giving power by people who has "power" to the powerless. While the bottom-up approach is understood as providing assistance from strong parties to the powerless to build their own base of power [19].

According to [11], [21] and [18], the role of community has a very large contribution of both provision or improvement of housing. This is closely related to the participation of the community, where each individual or group has different levels or participation form. According to Arnstein in Panudju (1999) in [22], community participation is classified into eight typologies, but can generally be grouped into three major groups which include (1) No community participation that includes manipulation and therapy, (2) Degrees of tokenism which includes informing, consulting and placation and (3) Degrees of citizen power includes partnership, delegated power and citizen control. Meanwhile, according to Holil (1980) in [23], the forms of participation include mind, energy, social participation, skills, goods, money, decision making, and representative participation.

\section{METHOD}

This study used post-positivism paradigm with historical research strategies [24]. Because the ultimate goal of this research is to describe the period of Kampung Improvement Program development in Surabaya comprehensively. So there were views taken from the past by looking at some of the available evidence (such as books, journals, research reports etc.) and supported by other data resources (stories) from some of the relevant interviewees.

Data collection was done through literature review and in-depth interviews. Interviewees were determined by using purposive sampling technique. After data collected, it were analyzed by using qualitative descriptive analysis. And used triangulation technique for data verification using different or multi resource.

\section{RESULT}

Based on the literature review that has been done, then the researchers can formulate that the criteria that can be used to arrange the period of Kampung Improvement Program are:

\section{Improvement Aspects}

1. Physical improvement aspects which includes : (a) infrastructure improvements, (b) improvements of public facilities and (c) improvement of physical occupancy

2. Social improvement aspects which includes : (d) mentoring, (e) training / coaching and (f) provision of facilities for human resource development

3. Economic improvement covering : (g) establishment of cooperatives, (h) business capital assistance, (i) stimulant funds, (j) business training, (k) housing financing and (l) tool assistance. 


\section{Empowerment}

4. Empowerment application which includes : (a) empowerment through knowledge, (b) empowerment through statue, (c) empowerment through resourcing and (d) empowerment through agreement and power transfer

5. Stages of empowerment which includes : (a) awareness, (b) interaction and learning, (c) mobilization or action and (d) contributions.

\section{Role}

6. Decision making with the application of the system (a) heteronomy / top-down, the government having a big role in decision making, (b) autonomy / bottom-up, the community that has a big role in decision making and (c) combination between heteronomy / top-down and autonomy / bottom-up

\section{Community participation}

7. Level of participation which includes : (a) no participation (manipulation and therapy), (b) Degrees of tokenism (informing, consulting, placation) and (c) Degrees of citizen power (partnership, delegated power and citizen control).

8. Form of participation which includes : (a) mind, (b) energy, (c) social participation, (d) expertise, (e) goods, (f) money, (g) decision-making, and (h) .

Based on the criteria of period which have been determined above, the researchers formulated there are four periods of development of Kampung Improvement Program in Surabaya.

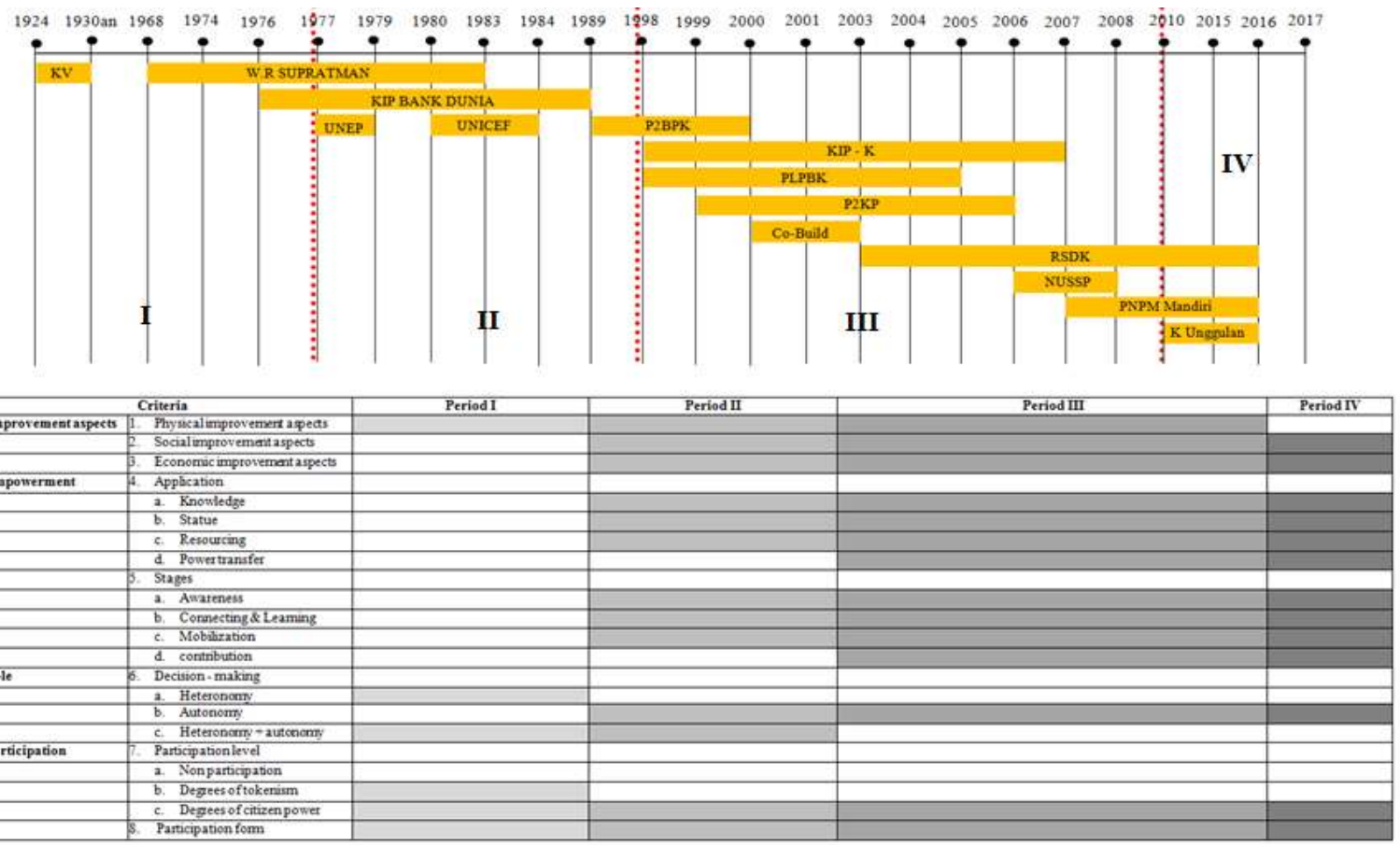

Figure 2. Period of Kampung Improvement Program Development in Surabaya

(Source : Researchers' Analysis, 2017)

In the first period, the focus of the improvement was only limited to the physical aspects associated with infrastructure improvements such as road and drainage channels improvement. However, there has been an increase in physical improvements in the implementation of the W.R Supratman program in the form of bridge and reservoir improvements, although the percentage is still minimal (only about $0.5 \%$ of the total location) (Sunarti in [14]). Improved of improvements aspect continue until the implementation of the World Bank's KIP program. Improvements not only to physical improvements in infrastructure (road improvements, sewerage and rain, clean water channels), there is an increase in physical improvements to public facilities such as the provision of elementary school buildings. In addition, there have been other social considerations for health improvement like MCK facilities, health posts, central health services (puskesmas), and handling of waste problems [15]. In the early period of development there has been no empowerment of the community in its implementation. And the program system is still dominated by heteronomy / top-down systems, where the 
dominant role of the government in the implementation of the program. However there has been community participation in each program, and the trend of participation rate is at the same level in the first period of development. However, in one program implementation, the level of participation has increased from degrees of tokenism into degrees of citizen power. This increase is due in part to the combined role of the community and government in the implementation of WR Supratman program. Because at the beginning of the W.R Supratman (1968 - 1973) implementation period, the improvement aspect was directly determined by the government due to the lack of funds owned by the government. Where all existing funds are made into materials such as concrete and concrete slabs, villagers can apply for the assistance of such materials and are willing to cover their own implementation costs [14]. But starting in 1974, the government had enough funds, so the system changed, assistance is cash but there is still participation from the community. Because there is still a donation of funds from the community with a percentage adjusted to the ability of the kampung concerned. And it is society that determines the components of improvement that must be addressed through community discussion. So the component of improvement in every kampung is not always the same, because the specified improvement component is a reflection of the needs of facilities for the existing kampung population (Sunarti in [14]). In general the form of participation in each program is the same in the form of money and energy but in the implementation of the World Bank KIP program form of community participation only in the form of space. This is because in the planning, implementation and financing, the villagers that received assistance are not at all involved, as all of them are handled by the Government through the Kampung Improvement Development Agency (Bappem KIP) [15].

The second period, there has been an enhancement in the improvement aspects that are handled in the implementation of the program. The aspects of improvement that are addressed not only focus on aspects of physical improvement, but already consider the social and economic aspects of the community who will receive the program. For example, the handling of social improvement aspects in the implementation of the UNEP and UNICEF KIP program has the same tendency to increase community development through training. Meanwhile, from the aspect of economic improvement, in improving the capacity of the community on the economic aspect, both programs have the same tendency is working capital assistance or loans from cooperative institutions to develop community businesses. In this period there has been community empowerment in the implementation of the program. But the difference is the application and stage of empowerment, where the tendency of empowerment application in the implementation of both programs more in the area of activities that can mobilize resources contained in groups or communities. Where communities have been helped to determine their own needs or concerns and solutions to address these issues. There is an effort by the government to involve the community in planning and decision making that is tailored to the needs of the community. However, for the stage of empowerment, it appears that the stages have increased from the stage of empowerment interaction and learning in the implementation of UNEP KIP increased to the stage of mobilization and action in the implementation of UNICEF KIP. Because the implementation of UNEP KIP the authority of the community in decision-making is still limited to the participation of individuals or communities through representation. And in this period, there was a noticeable change in the system where the former UNEP KIP system used in the program was a combined system between heteronomy system and autonomy system, which illustrates that the role of government and community is equally important in program implementation. This system began to change in the implementation of UNICEF KIP, where the system implementation of the program has been based on the community. All provisions are based on community decisions. Because the community has been able to determine the priority problem to be resolved and can determine the settlement of the problem. However, the level of participation of both programs is the same at the last level of participation, in which the people already have the authority to decide. The level of participation in this period shows an increase compared to the first period of participation, as both programs have the same level of participation. In general the form of participation in both programs are in the form of mind, energy, money, goods (material) and decision making.

The third period, the focus of improvement has been more comprehensive where all aspects of both physical, social and economic are equally noticed (known as the concept of tridaya). In this period overall empowerment application has been through grouping (institutionalized participation either in the form of Foundation of Kampung (Yayasan Kampung), Community Self-help Agency (BKM) or (LKM)). Where the empowerment stage has been at the most recent stage of contribution. The overall program objective is to empower the community, so that the most dominant role is the community. So people are required to be able to mobilize their resources independently to be able to meet the needs that suit their desires. Because the most dominant role is the community, so the level of community participation is in the third group that is community participation in the form of having power. Where at this level, people have full authority in decision making. Participation forms cover almost all forms of thinking, energy, expertise, money and even decision making. After the Comprehensive KIP program was implemented in Surabaya, the concept of the Comprehensive KIP program 
was widely adopted by the National government. One of the efforts of the Central Government to implement the concept of tridaya that can improve the quality of the settlement environment and at the same time improve the welfare of the community is through the implementation of Community Based Settlement Environment (PLPBK) program and through the implementation of Urban Poverty Program (P2KP) program which has been going on since 1999 and In 2007 the program transformed into PNPM Mandiri Urban program (PNPM MP). In addition, the program that also adopted the concept of KIP Comprehensive is a program of Local Social Rehabilitation of Slum (RSDK), this program also used tridaya concept, but the target of this program is a micro scope of villagers in the category of poor families. And all activity like preparation to arrange activity plan, selection and preparation of priority scale is determined based on the aspirations and discussed by the villagers themselves.

The fourth period, more emphasis on the development of human resources in the form of economic development. Because the two aspects of physical and social betting are considered to be quite good in implementing in previous programs. And the scheme of the program is more on increasing the potential that has been owned by the community with the support from the government. This illustrates that community empowerment has the largest portion compared to previous periods. Where community participation is the main focus in the implementation of the program. The program that entered in this period is known as Kampung Unggulan program. This program is a program by the Surabaya city government to manage ten kampungs that will be the center of small and medium industries (IKM). The program, which has been running since 2010, has empowered ten prominent kampungs with different characteristics. These characteristics include different products, habits, and educational backgrounds.

\section{Conclusion}

In this research has found eight criteria that can be used as a reference to arrange the period of Kampung Improvement Program development in Surabaya. These criteria includes:

\section{Improvement Aspects}

1. Physical improvement aspects

2. Social improvement aspects

3. Economic improvement aspects

\section{Empowerment}

4. Application of empowerment

5. Stages of empowerment

Role

6. Decision-making

\section{Community participation}

7. Participation level

8. Participation Form

In this research, it has also been found that there are four periods of Kampung Improvement Program Development in Surabaya. Based on the findings, it can be seen that actually, empowerment and participation are not programmed since the beginning of the period. However, in its implementation, community participation already exists. This proves that community participation in Surabaya has a good quality and big contribution for the successful implementation of Kampung Improvement Program. Therefore, in the second period of the program, there is a community empowerment that is more aware that community participation is needed. So in the third program development period, community participation began to be encouraged by institutionalizing the community's participation. And in the last period the improvement aspects of implementation program are more focused on human resources development, considering that aspect is needed for sustainable program.

\section{REFERENCES}

[1]. Ernawati, Rita, Santosa, Happy Ratna, \& Setijanti, Purwanita. (2013). Facing urban vulnerability through kampung development, case study of kampungs in surabaya, indonesia. Humanities and Social Sciences, 1(1), 1-6. doi: 10.11648/j.hss.20130101.11

[2]. Silas, Johan, \& Ernawati, Rita. (2013). Liveability of Settlements by People in the Kampung of Surabaya. Paper presented at the World Building Congress 2013.

[3]. Hanan, et al (2015). REFLECTIONS ON CREATIVITY: PUBLIC ENGAGEMENT AND THE MAKING OF PLACEIdentification of the Creative Capacity of Kampong's Community towards Sustainable Kampong (Case Studies: Cicadas and Pasundan Kampong, Bandung): A Preliminary Study. Procedia - Social and Behavioral Sciences, 184, 144-151. doi: http://dx.doi.org/10.1016/j.sbspro.2015.05.074.

[4]. Kementrian-PPN. (2005). Visi dan Arah Pembangunan Jangka Panjang (PJP) Tahun 2005 - 2025: Badan Perencanaan Pembangunan Nasional.

[5]. Poerbo, Hasan. (1978). Partisipasi Masyarakat dalam Perbaikan Permukiman Perkotaan : Sebuah Pendekatan yang Sedang Dicobakan di Bandung dan Surabaya. Proyek Penelitian dan Pengembangan dengan Bantuan Unite Nations Environment Programme (UNEP). Institut Teknologi Bandung. Bandung. 
[6]. Silas, Johan. (1989). Perumahan Penduduk Kota Berpenghasilan Rendah, Penggalan Sumberdaya dan Pola Pengembangan. Studi Kasus: Perumahan Kota Surabaya. Surabaya.

[7]. UN-Habitat. (2012). Sustainable Housing For Sustainable Cities : A policy Framework For Developing Countries. Nairobi.

[8]. Das, Ashok. (2015). Slum upgrading with community-managed microfinance: Towards progressive planning in Indonesia. Habitat International, 47, 256-266. doi: http://dx.doi.org/10.1016/j.habitatint.2015.01.004.

[9]. Ernawati, Rita, \& Santosa, Happy Ratna. (2014). Community Initiatives in Developing Sustainable Settlements, Case Study Kampung in Surabaya Indonesia. International Journal of Engineering Research \& Technology (IJERT), 3(6), 2242- 2245.

[10]. Dhakal, Shobhakar. (2002). Comprehensive Kampung Improvement Program in Surabaya as a Model of Community Participation.

[11]. Turner, John F.C. (1976). Housing By People Great Britain Marion Boyars Publishers Ltd.

[12]. Yudohusodo, Siswono, Salam, Soearli, \& Djoekardi, Djuwanda. (1991). Rumah Untuk Seluruh Rakyat Jakarta INKOPPOL, Unit Percetakan Bharakerta.

[13]. Peorbo, Hasan. (1981). Pendekatan Terpadu di dalam Pembangunan Daerah Perkampungan dan Permukiman Marjinal, Suatu Action Research yang Ditunjang Oleh United Nations Environment Programme di Bandung dan Surabaya, Pada Tahun 1977 1980. Paper presented at the Ceramah Kursus Perencanaan Sosial Pembangunan Kota VII, Sanur, Bali.

[14]. Silas, Johan. (1983). Perkembagan Program Perumahan dan Perbaikan Kampung di Surabaya. In J. Silas (Ed.), Program Perbaikan Kampung di Surabaya 1969 - 1982 Suatu Intervensi dan Evaluasi Surabaya: Badan Pelaksana Pembangunan Program Perbaikan Kampung Pemerintah Kotamadya Daerah Tingkat II Surabaya bekerjasama dengan Institut Teknologi 10 November Surabaya.

[15]. Surbakti, Ramlan, Sutrisno, \& Triharso, Ajar. (1986). Studi Perbandingan Antara Beberapa Program Perbaikan Kampung di Surabaya. Surabaya: Fakultas Ilmu Sosial dan Ilmu Politik, Universitas Airlangga Surabaya.

[16]. Alsop, Ruth, \& Heinsohn, Nina. (2005). Measuring Empowerment in Practice : Structuring Analysis and Framing Indicators. World Bank Policy Research Working Paper 3510.

[17]. Alsop, Ruth, Bertelsen, Mette Frost, \& Holland, Jeremy. (2006). Empowerment in Practice : From Analysis to Implementation.

[18]. Somerville, Peter. (1998). Empowerment through Residence. Housing Study 13(2).

[19]. Dugan, Maire A. (2003). On view of Empowerment. $\quad$ Retrieved 10 April 2016, from http://www.beyondintractability.org/essay/empowerment.

[20]. Ritzer. (1988). Developing a Tehory of Empowerment, In Search of a Meta-theory.

[21]. Arai, Susan M. (1997). Empowerment : From the Theoritical to the Personal. Journal of Leisurability, 24(1).

[22]. Yulianti. (2006). Partisipasi Masyarakat dalam Perbaikan dan Pemeliharaan Lingkungan Permukiman (Magister), Universitas Diponegoro, Semarang

[23]. Butar, Debora Catherine Butar. (2012). Penataan Lingkungan Permukiman Kumuh di Wilayah Kecamatan Semampir Kota Surabaya Melalui Pendekatan Partisipasi Masyarakat. JURNAL TEKNIK POMITS, 1(1), 1-6.

[24]. Groat, Linda, \& Wang, David. (2013). Architectural Research Method Second Edition (Second ed.). Canada John Wiley and sons, Inc.

Anita Dianingrum. "Development of Kampung Improvement Program in Surabaya, Indonesia." The International Journal of Engineering and Science (IJES) 6.7 (2017): 41-47. 